\title{
MODELLING OF TEMPERATURE IN FULL-SCALE SYSTEMS: A REVIEW OF THE BIOLOGICAL HEAT GENERATION WITHIN WINDROW COMPOSTING
}

\author{
Pemodelan Suhu pada System Skala Penuh: Kajian Pembangkitan \\ Panas secara Biologi melalui Komposting Udara Terbuka
}

\author{
Abdil Halimis Stani \\ Institute for Environmental Technology and Energy Economics \\ TU Hamburg-Harburg, Umwelttechnik und Energiewirtschaft \\ Harburger Schloßstraße 36, 21079 Hamburg \\ Email: abdil.stani@gmail.com
}

Diterima: 15 Juni 2012; Dikoreksi: 23 Juni 2012; Disetujui:31 Juli 2012

\begin{abstract}
Abstrak
Sistem komposting windrow adalah metode yang umum digunakan untuk pengolahan limbah padat oraganik. Temperatur adalah variabel yang penting dalam pemodelan yang mana dapat disimulasikan dengan memperkirakan perubahan keseimbangan panas dari komponen pada setiap saat. Energi panas biologis adalah istilah yang paling signifikan dalam keseimbangan panas. Dalam tulisan ini pembangkitan panas oleh proses komposting diuji dan dievaluasi dalam penerapannya untuk sistem windrow skala penuh. Sampai saat ini keakuratan memprediksi laju degradasi substrat telah menjadi tantangan utama. Penggunaan pendekatan induktif berdasarkan ekspresi kinetik orde pertama ataupun relasi kinetik empiris telah ditemukan untuk tujuan praktis. Bagaimanapunjuga faktor skala koreksi untuk proses dan tipe substrat tertentu mungkin dibutuhkan investigasi lebih lanjut untuk perbedaan sempit diantara skala lab dan skala sistem skala penuh.
\end{abstract}

Kata kunci: Komposting terbuka, keseimbangan panas, panas biologis, model pengkomposan

\begin{abstract}
Windrow composting is the most common method for organic solid waste treatment. Temperature is an important state variable in modelling, which could be simulated by estimating the change of heat balance components at any moment. Biological heat energy is the most significant term in the heat balance. In this paper biological heat generation of the composting process are examined and their applicability for a full-scale windrow system is evaluated. It is found that, to date, the accuracy of predicting the rate of substrate degradation has been a major challenge. The use of an inductive approach based on either first-order kinetic expression or empirical kinetics relation was found to be more feasible for practical purposes. However a scale-up correction factor for particular processes and types of substrate may need to be further investigated to narrow the discrepancies of kinetic performances between laboratory and full-scale systems.
\end{abstract}

Keywords: Windrow composting, Heat balance, Biological heat, Composting models

\section{INTRODUCTION}

Composting is a biological oxidative transformation that fulfils several waste management purposes such as stabilisation, volume reduction and sanitation by thermal inactivation of pathogens $[1,2]$. To accomplish these objectives, understanding the optimum condition may not be adequate since there may be conflicting variables during the composting process [3]. For example the range of temperature for optimal organic waste decomposition $\left(40-55^{\circ} \mathrm{C}\right)$ could be significantly different with the pathogen reduction (at above $55^{\circ} \mathrm{C}$ ) [5]. A trade off needs to be made to ensure that high the composting rate and sanitation may progress concurrently. There is a necessity to study explicit dependence of the composting rate in a broad range of environmental factors to allow better optimisation through calculation [3]. Therefore, mathematical modelling of the composting process has been receiving considerable attention for a wide range of purposes, ranging from understanding, 
describing, predicting, controlling to optimising the process $[3,5]$.

Temperature is a state variable that becomes a primary concern in composting models. Temperature is affected by heat flows resulting from temperature gradients. The temperature -time profile will represent the heat accumulation within a Windrow composting system since heat generated due to biological activity will be lost to the surrounding environment through ventilative losses, conduction, convection and radiation (CCR) mechanism, and turning/shifting compost pile. As a result, there are three states commonly found in a composting pile [4]:

Heat Generated > heat lost ---> temperature increases.

Heat Generated $=$ heat lost $\quad--->$ temperature static. Heat Generated < heat lost -.-> temperature decreases.

Temperature predictions and simulations within a composting process have been reported by $[6$, $7,8,9$ 10, 11]. The major differences in these models are the assumptions regarding the heat transport mechanism, and whether they are in a steady or an unsteady state condition, and also whether the process is modeled as a lumped or distributed parameter. All modelers used a series of one or two dimensional numerical calculations to reveal the temporal and/or spatial variations of the system temperature, whilst three dimensional mathematical models have just appeared within the past few years [12].

Despite the fact that a number of models for composting thermodynamics and kinetics have been published and reviewed [13, 14]), a standard appropriate model for full-scale Windrow composting has not been proposed. Windrow composting (i.e. piles with no active aeration) is the simplest, and the most common treatment method for organic solid wastes (Stentiford, 1996). However most of the aforementioned models were investigated in a laboratory and/or pilot scale study using an enclosed space or in vessel reactors (e.g. column, bin, container, tray or box). Therefore these models may not always properly simulate a physical variable profile of full-scale open composting system - particularly the duration and magnitude of temperature and moisture profiles [12] - due to a different physical composting environment. Various assumptions and simplifications used in experiments at less than full scale are sometimes unable to represent many aspects of commercial scale behaviour. The set-up of laboratory scale frequently may not be directly applicable to a full scale commercial facility. An example is the phenomenon of thermal inertia during the maturation stage.Self-insulating properties of compost materials, in which it coupled with microbial heat generation may lead to high thermopilic temperatures. Laboratory and pilot scale may fail to observe this phenomenon since temperature drops dramatically once the biodegradable organic matter is consumed [15].

Furthermore, temperature validations of simulated models within full-scale systems which have appeared in literature show unsatisfactory results. To date, there are no models which are capable of showing acceptable margins in terms of maximum, average, and peak temperature discrepancies. Since the energy generation due to microorganism's activity was found to be the most significant term in heat balance, the model of predicting biological heat generation is of paramount importance.The objective of this is to review and to evaluate the conceptual models of determining the biological heat components in composting process. Models published in literature will be classified according to their model building strategies, and the discussion will provide a basis for developing new and/or improved models for full-scale Windrow composting system.

\section{MATERIALS AND METHODS}

\subsection{Heat balance components}

The general heat balance model is based on the common laws of physics and thermodynamics, which states that total energy can be converted from one form into another over time. However it cannot be created nor destroyed, thus the sums of total energy in a system remain the same. Based on Mason's comprehensive review [13], there are several components of heat balance in composting models including a) sensible heats of the system (accumulation terms); b) radiative input, c) sensible heat of dry air, d) sensible heat of supplementary water, sensible and e) latent heat of inlet water vapour (input terms); f) sensible heat of dry exit gas, $g$ ) sensible heat of exit water vapour, h) conductive and convective loss, i) radiative losses, j) latent heat of water evaporation (output terms); and k) biological heat generation (transformation terms).

The most significant terms in the heat balance for a composting system at full scale have been identified as biologically generated heat [11] and the latent heat of vaporisation of water [10]. In contrast, several components $(2,3,4$, $6,7)$ may be neglected, incorporated into other components, or not implicitly distinguished in a separate term due to their small contribution in outgoing energy analysis. Therefore asimplified heat balance component in Windrow composting can be presented in Figure 1. 


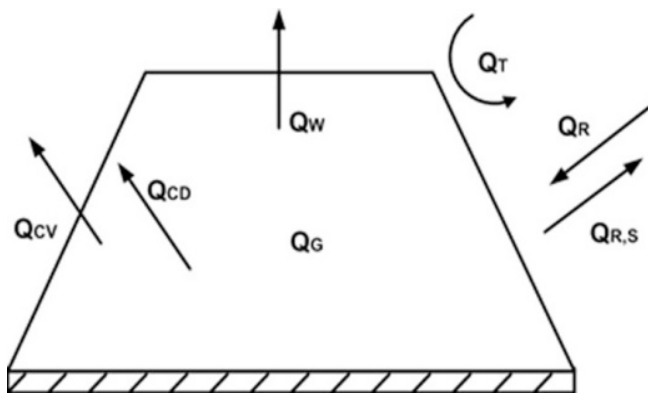

Figure 1. Heat balance within a Windrow pile

The process within a composting pile is aerobic, and the reactions are exothermic thus producing heat through biological transformations. As a result of the temperature difference between the volume unit and its surrounding environment, a conductive-convective heat loss occurred and radiative flux can be expected from the surface. In order to replenish oxygen, turning a Windrow is required on a regular basis, so the materials at the edges move into the center of the pile. However the Windrow temperature may drop rapidly due, to some extent, to heat loss with the outside ambient. Assuming sensible heat accumulation as the dependent variable, the heat balance in Windrow composting may be expressed by the general heat balance equations.

\subsection{Biological heat generation}

Biological heat generation is strongly associated with the rate of substrate degradation. Therefore it is necessary of having kinetic models that appropriately represent time-dependent behavior of microbial activity within the system. The rate of substrate degradation may be influenced by various process variables which have interrelations on time dependence. Thus several critical variables such as temperature, microbial group populations, and types of substrate, availability of water, oxygen concentration and inhibitors may be used as correction factors. In general, there are two strategies to model the composting kinetics. Seki and Shijuku, 2012 [21, 22] have recently introduced a non-biological kinetics model of estimating the heat generation rate by measuring the temperature changes during the composting process. Considering that the results of microbial activity is the most significant term of energy input, the heat generation rate calculated with this method may refer to biological heat. However this method may be not applicable as a basis for developing temperature simulation models, since the temperature changes considered as input variables.

\section{RESULTS AND DISCUSSION}

\subsection{Evaluation of Three Different Models}

The wide range approaches of determining biological heat may leave a big questionmark as to the extent of the differences. To investigate the theoretical outcomes, three composting models were selected, the first one $[23,24]$ as a representative of first-order models, the second one $[15,25]$ as a representative of empirical kinetics determination and the third [26] as a representative of Monod-type models. For simplification, it is assumed that initial temperature is $20^{\circ} \mathrm{C}$, then rises gradually due to biological heat generation. There is no energy dissipated, oxygen and moisture content are constant during the first 12 hours of composting process. The aeration is sufficient, and thus there is no inhibitor accumulation

Identical operating conditions were used as shown in Table 1. The organic matter degradation (manure) proceeds according to the following reaction:

$\mathrm{C} 22 \mathrm{H} 37 \mathrm{O} 5 \mathrm{~N} 3+(33 / 2) \mathrm{O} 2 \mathrm{C} 5 \mathrm{H} 7 \mathrm{O} 2 \mathrm{~N}+12 \mathrm{CO} 2$ $+10 \mathrm{H} 2+\mathrm{NH} 3$

The reaction rate coefficients are corrected based on formulas given in Table 2. Figure 2 shows the simulation of theoretical biological heat based on three difference methods in 12 hours. It can be seen that at the first $18000 \mathrm{~s}$, the Monod -expression kinetics gave the highest values in the ranges of $29-40 \mathrm{~J} / \mathrm{s}$, followed by the first-order and empirical kinetics in the ranges of 20-32 J/s and 18-24 J/s, respectively. As a consequence, the Monod-expression reached the temperature of $30^{\circ} \mathrm{C}$ earlier than first-order and empirical.

The first order model yields the fastest rate of increment and, at about 30.000 s, it exceeds the Monod-expression model. Although the Monod -expression model reaches the thermophilic phase $\left(40^{\circ} \mathrm{C}\right)$ earlier, however, the rate of first order reaction is much faster than the Monod -expression. The empirical kinetics show the slowest rate of reactions from the beginning to the end (43200 s or $12 \mathrm{~h}$ reaction), and the estimated heat also gives the smallest values during this period. Once the first order kinetics reached the thermophilic phase at about 36000 $\mathrm{s}$, the simulation showed greater degrees of discrepancies. First order substrate degradation increased dramatically with the value at above $70 \mathrm{~J} / \mathrm{s}$, whilst Monod-type and empirical kinetics at approximately 60 and $35 \mathrm{~J} / \mathrm{s}$, respectively. 
Table 1. State variables and constant used in the models

\begin{tabular}{|c|c|c|c|}
\hline Parzmeter & Symbol & Value & References \\
\hline Manere uaste & $s$ & $20.6 \mathrm{~T} \mathrm{~kg}$ & r \\
\hline Volvole frection of the manure solids & $v_{s}$ & 1216 & Ndezua et al. Roops \\
\hline Manere solids fraction & $\mathrm{s}_{\mathrm{m}}$ & 1654 & Ndegua et al. (2000) \\
\hline Dcqradahility coefficieal of narure & $\mathrm{K}_{\mathbf{m}}$ & 0.76 & Hane (1933) \\
\hline Free air space & EAS & 0.13 & - \\
\hline Oxypen cuncertination & $\mathrm{O}_{2}$ & $20 \%$ & - \\
\hline Fasl fraction of BVS of matre & BVS, & a.? & Nulequa ct al. (260) \\
\hline Slow fraction of BVS of manare & BVS, & 0.3 & Nidegua et al. (2000) \\
\hline Fast resction rate of BVS of nanure & $K_{n}$ & oosid & Ndezua et al. (2000) \\
\hline Slow reactien rone of HVS of maure & K. & oossid & Ndezua st al. 12000s \\
\hline Heat of combustion of manure & $\Delta H_{,}$ & $1.54 \mathrm{Mvikg}$ & Van Girkel (1595) \\
\hline Censtank & a & $8 \times 3 \mathrm{E}^{\mathrm{k}} \mathrm{kg} / \mathrm{h}$ & Petric and Selinbesic (2008) \\
\hline Censtark & b & 1.0535 & Petric and Selinbesie (2008) \\
\hline Consart & c & 1.2247 & Petric and Selinhesic C(00s) \\
\hline Order of reaction & $\mathrm{n}$ & 28944 & Petric and Selinibubie (2005) \\
\hline Bistrabs cuactrintion & $\mathrm{S}_{*}$ & 0.035 kg'm' & Bonerchecteded and btäb; $200 \times$ ) \\
\hline Censais ccentan! & $\mathrm{K}_{\text {, }}$ & 0.05 & Benerchesteded and Btraty, 2008) \\
\hline Half-xaluratiun coefficizul & K, & ans & Bonechectedkal and Btäy, 2008) \\
\hline Activadicen cuengy of bicenwes & E & 23500K.imale & 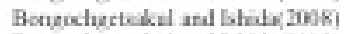 \\
\hline Activasion mergy of ticonass intibetion & $\mathrm{E}_{\mathrm{z}}$ & $250000 \mathrm{~K}$ imole & Bengochectsokel and lishady(2008) \\
\hline Arrterius poe exponential fosisar & $A_{r}$ & 0.195715 & Bengocheretsakal and lshadx:2008) \\
\hline Anterius constam & $\mathbf{K}_{r}$ & $2 E^{n}$ & Bengochestsokel and lsteds; 2008) \\
\hline Minimem volametric wakr contere & 9 & 4.ins & Bengocheretsikel and lshadx;2008) \\
\hline Maximum volenctric valer coutcul & 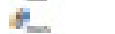 & $28 \%$ & Bonerchecteded and Btraty (2008) \\
\hline Optimam vulunetric wast curient. & ent & $25.4 \%$ & Bonerchectedel and Btrate (2008) \\
\hline Yield coefficieal & $Y^{m}$ & & Siveichionctric caksulation \\
\hline
\end{tabular}

Table 2. Reaction rate coefficient correction factors

\begin{tabular}{|c|c|}
\hline Equations & Reforences \\
\hline 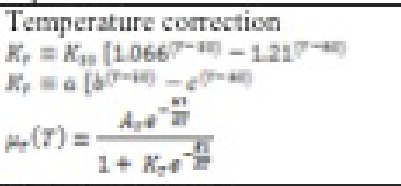 & 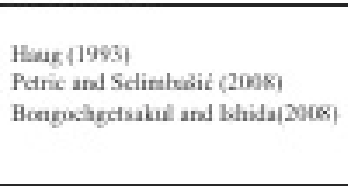 \\
\hline \multicolumn{2}{|l|}{ Moisture correction } \\
\hline 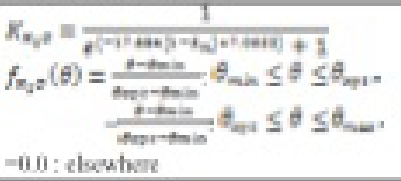 & 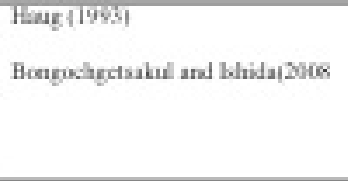 \\
\hline Oxygen correction & \\
\hline $\begin{array}{l}K_{h_{2}}=\frac{V O_{2}}{V O_{2}+2} \\
f_{h_{2}}\left(O_{3}\right)=\frac{O_{2}}{K_{2}+O_{2}}\end{array}$ & 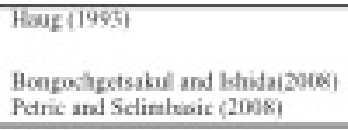 \\
\hline \multicolumn{2}{|l|}{ Substrate reduction factor } \\
\hline$f(S)=\frac{s}{K_{2} x+s}$ & Petric and Selinbedic (2008) \\
\hline \multicolumn{2}{|l|}{ Free air space correction } \\
\hline 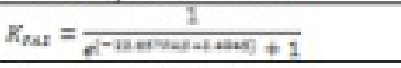 & Haug (1995) \\
\hline Net rate coefficient & \\
\hline 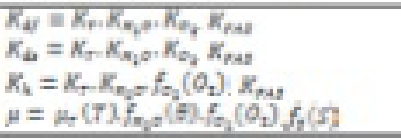 & 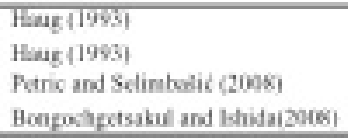 \\
\hline
\end{tabular}

\subsection{Model Application}

In practice, some limitations appeared in all approaches. When the heat generation is estimated by the first order assumption; the kinetic parameters of waste degradation (k) were determined in a laboratory-scale. Then this parameter is applied into model to predict the full -scale behaviour of composting systems. Baptista et al. 2012 [2] found that the kinetic rate of waste degradation in full-scale systems, which is proportional with metabolic heat generation, is much lower than laboratory-scale studies. It is shown that the kinetic performance of laboratory -scale studies is, on average, 5.7 times faster than commercial level. Moreover, the other data show that the chicken manure composting model 
simulates characteristics well over a short time period (approximately 3 days).

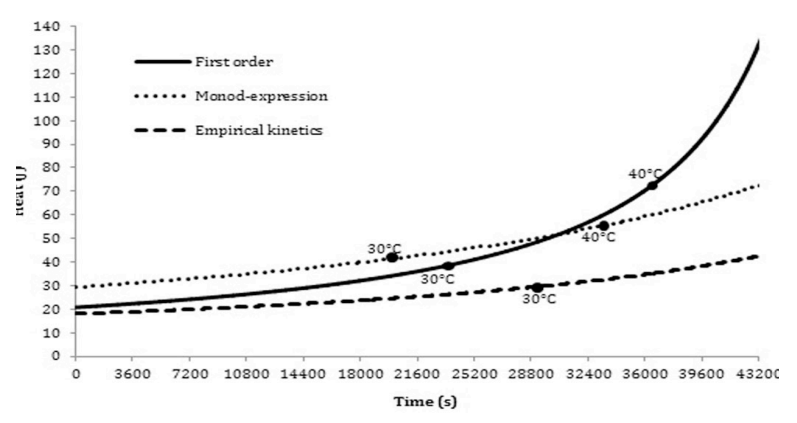

Figure 1. Comparisons of biological heat generation.

In the case of yard waste the model is applicable over a much longer period once the peak activity has been reached [26]. After such a period the rate coefficient may need to be adjusted in order to reflect the changes in waste composition. In the case of empirical kinetics model, the poultry manure composting experiment of Petric and Selimbašić, 2008 [15] shows that the model is under-predicted over a short time (over the first 24 hours), but the model is more applicable at peak and longer time. Therefore the Monod approach may also have some drawbacks to be applied on a broader basis for mixed and variable microbial composting populations, due to difficulties in parameter estimation. Monod-type models require an estimate of initial microbial mass [27, 28], usually use the values of kinetic parameters from available literature, which in most of the cases $[29,30]$ are not calibrated. Moreover models incorporating Monod-type expressions are found to be less successful in simulating the profiles of the temperature (Mason, 2006).

\section{CONCLUSIONS}

The accuracy of predicting the rate of biological heat is still a major challenge. The use of an inductive approach of determining degradation rate based either on first-order kinetic expression or empirical kinetics relation is more feasible for practical purposes. For first order kinetics, scale -up correction factors for particular processes and types of substrate may need to be developed to narrow the discrepancies of kinetic performances between laboratory and full-scale systems. In addition, the method of updating the rate constant based on the changes in waste composition into account need to be investigated. Whilst, empirical kinetics models are less universal in nature, however, this method is advantageous for waste-/ site-specific composting plants.The major problems associated with Monod-type expressions are the large numbers of operation parameters. The increase in parameters may result in an increase in the uncertainty of the prediction. However this does not mean closing the opportunity to apply Monod-kinetic based energy generation into commercial scale. If a standard protocol for composting studies at laboratories scales, especially the method of determination operation parameters were developed the problems associated with the uncertain accuracy of the parameters in the mechanistic model would be diminished. The parameters may be calibrated and more adoptable for broader applications.

\section{REFERENCES}

1. Bach, P.D., Nakasaki, K., Shoda, M., Kubota, H., 1987. Thermalbalance in composting operations. Journal of Fermentation Technology65 (2), 199-209.

2. Baptista, M., Silveira, A., Antunes, F., 2012. Theoritical analysis of the kinetic performance of laboratory- and full-scale composting systems. Waste Management \& Research 30 (7), 700-707.

3. Barrena, R., Canovas, C., Sánchez, A., 2006. Prediction of temperature and thermal inertia effect in the maturation stage and stockpiling of a large composting mass. Waste Management 26, 953-959.

4. Bari, Q.H., Koenig, A., 2012. Application of a simplified mathematical model to estimate the effect of forced aeration on composting in a closed system. Waste Management 32, 2037-2045.

5. Bongochgetsakul, N.,Ishida, T., 2008. A new analytical approach to optimizing the design of large-scale composting systems. Bioresource Technology 99, 1630-1641.

6. Das, K., Keener, H.M., 1997. Numerical model for the dynamic simulation of a large scale composting system. Transactions of ASAE 40 (4), 1179-1189.

7. De Bertoldi, M., Vallini, G., Pera, A., 1983. The Biology of composting: Areview. Waste Management \& Research 1, 157-176.

8. De Guardia, A., Petiot, C., Benoist, J.C., Druilhe, C., 2012. Characterization and modelling of the heat transfers in a pilot-scale reactor during composting under forced aeration. Waste Management 32, 1091-1105.

9. Finger, S.M., Hatch, R.T., Regan, T.M., 1976. Aerobic microbial growth in semi-solid matrices: heat and mass transfer limitations. Biotechnology and Bioengineering 18, 1193-1218.

10. Fontenelle, L-T., Corgié, S.C., Walker,L.P., 2011. Integrating mixed microbial population dynamics into modeling energy transport during the initial stages of the aerobic composting of a switchgrass mixture. Bioresources Technology 102, 5162-5168.

11. Fujita, K. 1993. Composting technology. Gihodoshuppan, Tokyo, 196 pp. (In Japanese).

12. Mason, I.G., Milke, M.W., 2005b. Physical modelling of the composting environment: A review. Part 2: Simulation performance. Waste Management 25 (5), 501-509.

13. Mason, I.G., 2006. Mathematical modelling of the composting processt: A review. Waste Management 
25, 3-21.

14. Mohee, R., White, R.K., Das, K.C., 1998. Simulation model for composting cellulosic (bagasse) substrates. Compost Science and Utilitzation 6 (2), 82-92.

15. Petiot, C., de Guardia, A., 2004. Composting in a laboratory reactor: a review. Compost Science \& Utilization 12, 69-79.

16. Petric, I., Selimbašić, V., 2008. Development and validation of mathematical model for aerobic composting process. Chemical Engineering Journal 139, 304-317.

17. Robinzon, R., Kimmel, E., Krasovitski, B., Avnimelech, Y., 1999. Estimation of Bulk Parameters of a Composting Process in Windrows. Journal of Agricultural Engineering Research73 (2), 113-121.

18. Robinzon, R., Kimmel, E., Avnimelech, Y., 2000. Energy and massbalances of windrow composting system. Transactions of ASAE 43(5), 1253-1259.

19. Ramasamy, V.P., Bokhoree, C., 2008. Robust numerical windrow system simulation for decomposition of Organic Waste. In: Proceedings of the 2008 International Conference on Scientific Computing, CSC 2008, July 14-17, 2008, Las Vegas, Nevada, USA.

20. Scholwin, F., Bidlingmaier, W., 2003. Fuzzifying the composting process: a new model based control strategy as a device forachieving a high grade and consistent product quality. In: Proceedings of the Fourth International Conference of ORBIT Association on Biological Processing of Organics: Advances for a Sustainable Society, 30th April-2 May, 2003, Perth, Australia. ORBIT Association, Weimar, Germany, pp. 739- 751.

21. Seki, H., 2000. Stochastic modeling of composting processes with batch operation by the FokkerPlanck equation. Transactions of ASAE 43 (11), 169-179.

22. Seki, H., Shijuku, T., 2012. Estimating the heat generation rate in a forced-aeration composting process by measuring temperature changes. Journal of Agriculture Meteorology 68 (2), 107-120.

23. Sidhu, H.S., Nelson, M.I., Chen, X.D., 2007. A simple spatial model for self-heating compostpiles. Journal of theAustralian Mathematical Society (41), C135-C150.

24. Smith, R., Eilers, R.G., 1980. Numerical simulation of activatedsludge composting. EPA -600/2-8C-191, USEPA, Cincinnati, OH,USA.

25. Sole-Mauri, F., Illa, J., Magri, A., Prenafeta -Boldu, F.X., Flotats, X., 2007. An integrated biochemical and physical model for the composting process. BioresourceTechnology 98, 3278-3293.

26. Stentiford, E., de Bertoldi, M., 2011. Composting: Process, in: Christensen, T.H. (Eds.), Solid Waste Technology and Management. Wiley, Blackwell Publishing, UK, pp. 515-532.

27. Stombaugh, D.P., Nokes, S.E., 1996. Development of a biologically based aerobic composting simulation model. Transactions of ASAE 39 (1), 239-250.

28. Sundberg, C., 2005. Improving compost process efficiency by controlling aeration, temperature and $\mathrm{pH}$. Doctoral Thesis, Swedish University of Agricultural Science Uppsala.

29. vanLier, J.J.C., van Ginkel, J.T., Straatsma, G., Gerrits, J.P.G., vanGriensven, L.J.L.D., 1994. Composting of mushroom substrate in a fermentation tunnel - compost parameters and a mathematical model. Netherlands Journal of Agricultural Science 42 (4), 271-292.

30. Watanabe, O., Isoda, S., 2011. Integrated model of reaction rate equations and thermal energy balance in aerobic bioreactor for food waste decomposition. Journal of Environmental Sciences 23, S84-S89. 